\title{
Snakeheads of Sri Lanka: A Taxonomic and Biogeographic Review
}

\section{W. P. Naalin Perera ${ }^{1 *}$, Sandun J. Perera ${ }^{2}$, Chaminda N. Walpita ${ }^{3}$, Suranga Kodithuwakku ${ }^{4}$, Lasith V. Perera ${ }^{5}$ and Ajith Gunawardane ${ }^{6}$}

Date Received: $10^{\text {th }}$ April 2020 / Date Accepted: $27^{\text {th }}$ June 2020

\begin{abstract}
Purpose : Fish species of the family Channidae, commonly known as snakeheads, represent biggest and most caught native freshwater species in Sri Lanka. Despite importance for biodiversity and fisheries in Sri Lanka, members of this family are one of the least studied on taxonomic status and geographic distribution.

Research Method: As an initial step of a study to revise the taxonomy and biogeography of freshwater fish in the family Channidae based on molecular phylogenetic and morphological relationships and biogeographical affinities, authors reviewed all the available published information and examined the specimens available at the National Museum of Sri Lanka.

Findings : Six valid species have been recorded; Channa ara (Deraniyagala, 1945), C. marulius (Hamilton, 1822) C. kelaartii (Gunther, 1861), C. orientalis Bloch and Schneider 1801 C. punctata (Bloch, 1794) and C. striata (Bloch, 1793). Current review suggests the exiting knowledge on the phylogeny and biogeography of Channidae in Sri Lanka is far from complete, identifying specific gaps to be prioritized in future research.

Limitations : Current regional studies on the family Chanidae highlight the importance of a complete systematic revision of Sri Lankan species with an integrative approach. Literature review shows the necessity of a fresh analysis on the distribution data with ecological niche modeling and molecular phylogenetic studies to understand biogeographical and evolutionary history of the family.
\end{abstract}

Originality / Value : Provides a consolidated account of the current knowledge on the taxonomy and biogeography of the Sri Lankan members of the family Channidae.

Keywords: Biogeography, Channa, Channidae, DNA barcoding, Ichthyo-zoogeography, Taxonomy

\section{INTRODUCTION}

Snakeheads are described as a group of freshwater fish belonging to family Channidae, characteristically identified by their prominent snake-like head with large scales and the distinct mouth with sharp teeth (Jayaram, 1999; Gurumayum and Tamang, 2016). They are predatory in nature and carnivorous as adults reach comparatively large sizes (i.e. Talwar and Jhingran (1991) was recorded $122 \mathrm{~cm}$ lengh for Channa marulius) except for few species, vivid colourations in many, and inhabit most countries in Asian region. These characters earned them a reputation as hardy fish easy to grow, and a highly valued, both in food fish industry and ornamental trade worldwide. Same characters are also

\footnotetext{
1 Faculty of Graduate Science, Sabaragamuwa University of Sri Lanka, P.O. Box. 2, Belihuloya, Sri Lanka.

naalin@gmail.com

2 Department of Natural Resources, Faculty of Applied Sciences, Sabaragamauwa University of Sri Lanka, P.O. Box. 2, Belihuloya 70140.

3 Department of Livestock Production, Faculty of Agricultural Sciences, Sabaragamuwa University of Sri Lanka,P.O. Box. 2, Belihuloya, Sri Lanka.

4 Department of Animal science, Faculty of Agriculture, Peradeniya University, Belihuloya, Sri Lanka.

5 Faculty of Applied Sciences, Sabaragamuwa University of Sri Lanka, Belihuloya, Sri Lanka.

6 Central Environmental Authority, Densil Kobbekaduwa Mawatha, Baththaramulla.
}

(1) ORCID http://orcid.org/0000-0002-5790-3863 
attributed to their invasive nature in introduced habitats (Courtenay and Williams, 2004). They are characterized by peculiar morphological features, such as an elongated cylindrical body, long and entirely soft-rayed dorsal and anal fins, a large mouth with well-developed teeth on both upper and lower jaws, vomer and palatine bones of the skull, and an accessory air-breathing apparatus known as the suprabranchial organ, as it is situated in the suprabranchial cavity in the head (Talwar and Jhingran, 1991; Jayaram, 1999). The snakeheads (Actinopterygii: Perciformes: Channidae) comprise more than 40 valid species in three genera; Channa, Parachanna and Aenigmachanna (Li et al., 2006; Serrao et al., 2014; Britze et al., 2019; Praveenraj et al., 2019; Sudasinghe et al., 2020a). Snakeheads of the genus Channa are distributed mainly in tropical Asia, and Parachanna in tropical Africa, while Aenigmachanna with only a single species recorded from South India (Li et al., 2006; Britze et al., 2019).

Some members of the genus Channa including C. striata, C. marulius and C. micropeltes are main edible fish across most of the Asia (Willey, 1910; Talwar and Jhingran, 1991; Li et al., 2006; Wimalasena and Jayasuriya, 2013). Being edible, some members of this genus have even been introduced to new geographical areas in Asia as food fish, while a few has been accidentally released into biogeographically new locations via ornamental fish trade. For example, Channa striata has been introduced to Fiji, Papua New Guinea, New Caledonia and Hawaii as a food fish (Li et al., 2006). Mustafa et al., (2013) and Wimalasena and Jayasuriya (1996) have studied the aquaculture and nutritional value of Channidae. Further, genus Channa has been studied not only for its nutritional value, but also for the medicinal value (Mustafa et al., 2012; Mustafa et al., 2013).

In Sri Lanka, the Family Channidae is represented only by the genus Channa Scopoli, 1777. Willey (1909), Duncker (1912), Deraniyagala (1929, 1932, 1945, 1952, 1963), Mendis and Fernando (1962), Senanayake (1980), Pethiyagoda (1991), De Silva et al., (2015), and Sudasinghe et al., (2020a), Sudasinghe et al., (2020b) have provided accounts of ecology, distribution and the taxonomic status of the family Channiade in Sri Lanka. All six species of this genus, are native to Sri Lanka, namely, Channa ara (Sri Lanka giant snakehead), Channa marulius (giant snakehead), Channa striata (murrel), Channa orientalis (Sri Lanka smooth-breasted snakehead), Channa punctata (spotted snakehead), and Channa kellarti (brown snakehead). All members of this genus in Sri Lanka are restricted to freshwater and occasionally recorded in brackish water, while they usually play the role of predator in their habitats. Some members are commercially harvested in significantly large numbers for consumption (e.g. Channa striata) and aquarium trade (C. marulius and $C$. orientalis) (Willey, (1910; Pethiyagoda, 1994; Amarasinghe et al., 2006; De Silva et al., 2015). Although these six species have currently been accepted in the Sri Lankan publications of freshwater fishes (Goonatilake, 2012; Goonatilake et al., 2020; Sudasinghe et al., 2020a; Sudasinghe et al., 2020b), the need for a taxonomic reassessment of the genus in Sri Lanka is discussed in this paper.

The main objective of this review was to comprehensively assess the current status of the family Channidae of Sri Lanka using all available data on the morphological, molecular phylogenetic and distributional aspects of Sri Lankan Channids. Further, it was intended to identify gaps in knowledge related to the taxonomy, and molecular phylogenetic and biogeographic relationships in Sri Lankan members of the family Channidae.

All literature publish on the family Channidae in Sri Lanka were reviewed and discussed in this paper as an initial step of a study to revise the taxonomy and biogeography of Channids. Taxonomic reviews, monographs, species descriptions and other related literature were used to determine the current status of knowledge on the family. Further, we examined the specimens of Channids available at the National Museum of Sri Lanka. Additional details of the review when and where relevant are provided below, 


\section{RESULTS AND DISCUSSION}

\section{Taxonomy of the Family Channidae in Sri Lanka}

Previous work on the taxonomy of family Channidae in Asia including Sri Lanka recognized two genera; Channa Scopoli 1777 and Ophicephalus Bloch 1793. Members of the genus Channa were distinguished from those of the genus Ophicephalus by not having pectoral fins, which however is present only in a single species of Channa, i.e. C. orientalis. In current taxonomic treatments Ophicephalus Bloch 1793 is considered as a synonym of Channa (Pethiyagoda, 1991; Kotteilat, 2013). According to the current and historically published literature on freshwater fishes of Sri Lanka including Gunther (1861), Duncker (1912), Deraniyagala (1929, 1932, 1945, 1952, 1963), Munro (1955), Mendis and Fernando (1962), Senanayake (1980), Pethiyagoda (1991), Goonatilake (2012), De Silva et al., (2015), Goonatilake et al., (2020), and Sudasinghe et al., (2020a) and Sudasinghe et al., (2020b) the genus Channa is represented in Sri Lanka by six valid species viz. Channa ara (Deraniyagala, 1945), Channa marulius (Hamilton, 1822), Channa kelaartii (Gunther,1861), Channa orientalis Bloch and
Schneider 1801, Channa punctata (Bloch, 1794) and Channa striata (Bloch, 1793). According to the recent national literature on Sri Lankan Channidae (Goonatilake, 2007, De Silva et al., 2015, Goonatilake et al., 2020, Sudasinghe et al., 2020a,), two species of snakeheads, Channa ara, and $C$. orientalis, are considered as endemic to the island.

Lateral line scales, the number of rays in fins, number and size of scales, cephalic scales, absence or relative size of pelvic fins, teeth, relative body lenghth sizes and colourtaion are major taxonomic characteristics which had been used in the taxonomy of Channidae (Gunther, 1861; Deraniyagala,1929, 1932，1945，1952; Jayaram, 1999; Britz et al., 2017; Sudasinghe et al., 2020a and Sudasinghe et al., 2020b). In his treatment of the fishes of Sri Lanka, Deraniyagala (1952) provided the review of the Family Channidae including a key to all Sri Lankan species, also providing an illustrated guide to the scale pattern on the head, which can be used to species level identification (Figure 01). However, Deraniyagala's (1952) cephalic scalation has not yet been followed up since then, with neither any critiques nor further improvements.. (a)

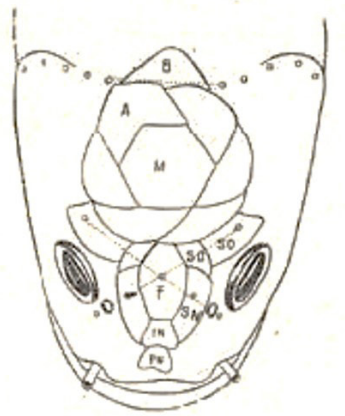

(d)

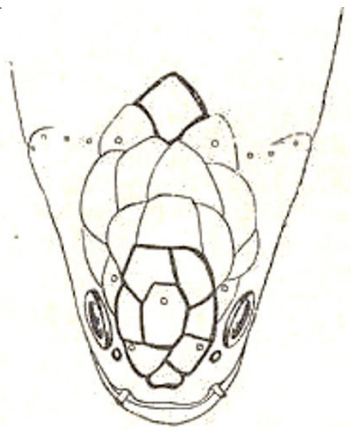

(b)

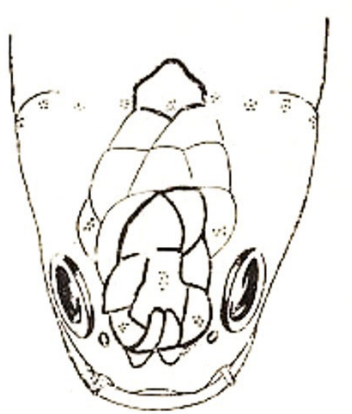

(e)

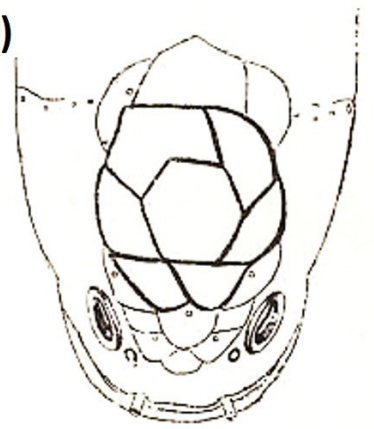

(c)

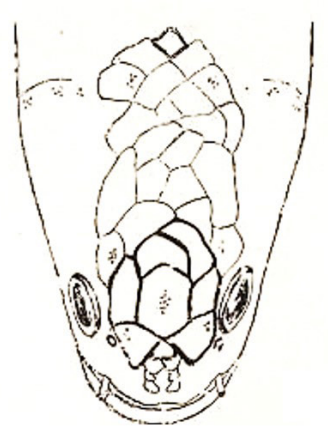

(f)

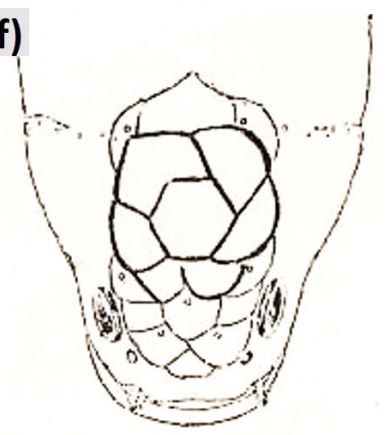

Figure 01: Cephalic scutes of Sri Lankan Channa species (After Deraniyagala 1952): (a) a schematic head showing pores and scutes, (b) $C$. marulius ara, (c) $C$. striata, (d) $C$. punctata, (e) $C$. gathua kelaartii, and (f) C. orientalis. 
In the description of Channa orientalis (the type species of the genus) by Bloch \& Schneider in 1801 , its type locality is given as "Habitat in India Orientale", which is in confusion with Sri Lankan endemic status of the species. According to literature, neither Bloch nor Schneider has visited Sri Lanka or India personally, and their work was based on about fifteen hundred specimens in a collection owned by M.E Bloch (Karrer et al., 1994). Bloch has received specimens from all over the world. Hence, it is quite possible that the type specimen of Channa orientalis originally being collected from Sri Lanka may have been received by him with an Indian collection. It can also be argued that he might also have had a doubt about the type locality as it is given with the suffix "Orientale" after India, which represented the entire south and southeast Asian region at that time (Sclater, 1858; Wallace, 1876). Furthermore, in addition to its type locality being confused with India, recently published records of specimens phenotypically presumed by authors as Channa orientalis, from peninsular India questions its endemic status in Sri Lanka (Sarrao et al., 2014; Sharma et al., 2015). However, Mishra et al., (2014) shows that Indian specimens that were treated as Channa orientalis do not belong to the same species and confirmed the restriction of $C$. orientalis to Sri Lanka.

Sudasinghe et al., (2020b) has recently revised the status of Channa gachua of Sri Lanka and south India and re-erected Channa kelaartii as a valid species which is restricted to Sri Lanka and Southern India.

Further, Sudasinghe et al., (2020a) has recently revisited the Channa marulius group of Sri Lanka, where they distinctly identified the population of Mahaweli river as a valid species. The name Channa ara has been assigned referring to the subspecies description of Ophicephalus marulius ara by Deraniyagala (1945). Further, the northern dry zone population of that group was confirmed to remain as Channa marulius, while the southwestern wet zone population has been treated as a taxonomic ambiguity.

Further, a multitude of colour varieties have been recorded from geographically disjunct populations within the island, Channa ara and Channa orientalis needs further investigation at local geographic scale within Sri Lanka. All in all, a considerable level of taxonomic ambiguity exists within the genus Channa in Sri Lanka (e.g. population of Channa ara in the south western part of Sri Lanka has not been included into any valid species, even after the taxonomic revision by Sudasinghe et al., (2020a).

Sri Lankan species of Channa and their current taxonomic status can hence be summarized as follows;

1. Channa ara (Deraniyagala, 1945).

Ophicephalus marulius Hamilton, 1822

Type locality: Gangetic provinces, India

Ophicephalus marulius ara (Deraniyagala 1945)

Type locality: Ceylon

Channa cf. ara Sudasinghe et al., 2020

Type locality: Southwestern wet zone of Sri Lanka

Further taxonomic studies, especially those involving molecular techniques are needed to clarify the status of the southwestern wet zone population of Channa cf. ara (Sudasinghe et al., 2020a). Further a detailed reassessment of the taxonomic history and biogeographic limits of $C$. ara and $C$. marulius would result in taxonomic stability of the C. marulius group in Sri Lanka.

2. Channa marulius (Hamilton, 1822).

Ophicephalus marulius Hamilton, 1822

Type locality: Gangetic provinces, India

Ophicephalus marulius ara (Deraniyagala 1945)

Type locality: Sri Lanka

Further taxonomic studies, especially those involving molecular techniques are needed to clarify species limits between Channa $c f$. ara Sudasinghe et al., (2020a) and Channa marulius (Hamilton, 1822). 


\section{Channa kelaartii (Gunther,1861).}

Ophiocephalus gachua Hamilton, 1822

Type locality: ponds and ditches of Bengal, India.

Ophiocephalus kellarti Gunther, 1861

Type locality: Ceylon

Channa gachua kellarti Gunther, 1861

Type locality: Ceylon

Channa kelaartii has been listed for Sri Lanka by De Silva et al., (2015), which had been documented by Deraniyagala (1945) as Channa gachua kelaartii. Although, during initial work Ophiocephalus kelaartii was synonymized with O. gachua (sensu Day, 1878), recent molecular genetic studies (Conte-Grand et al., 2017) has confirmed Channa kelaartii to be genetically different from C. gachua. Sudasinghe et al., (2020b) has confirmed the validity of Channa kelaartii, and further noted that occurrence of the species in south India. Ophiocephalus is an incorrect spelling of Ophicephalus Bloch (Sudasinghe et al., 2020b)

4. Channa orientalis Bloch and Schneider 1801 ,

Type locality- India "orientale",

Although, few Indian publications (Jayaram, 1999; Sharma et al., 2015) have mentioned the occurrence of Channa orientalis in Indian mainland, molecular genetic studies have revealed the species as a distinct lineage endemic to Sri Lanka (Conte-Grand et al., 2017). Multiple authorships exist for the species $C$. orientalis in previous publications, i.e. in Mendis and Fernando (1962) as 'Bloch' and in Jayaram (1999) as 'Schneider'. Karrer et al., (1994), reviewed the original work by Bloch and Schneider and suggested authorship for the taxon as "Bloch and Schneider 1801".

\section{Channa punctata (Bloch, 1794),}

Ophicephalus punctatus Bloch, 1794

Type locality- Malabar Coast
A common freshwater species in Sri Lanka and widely distributed from Afghanistan to southern China including India, Pakistan and Bangladesh. According to Conte-Grand et al., (2017), this species is characterized by deep intraspecific divergences and hence could be split into multiple lineages. Further, Sri Lankan population of $C$. punctata is yet to be genetically evaluated to ascertain its identity.

\section{Channa striata (Bloch, 1793),}

Type locality - Malabar, southwestern India

A common freshwater species in Sri Lanka and widely distributed from Pakistan to most drainages of India, southern Nepal, Bangladesh, Myanmar, Thailand, Cambodia, southern China, and the Malay Archipelago including Malaysia, Sumatra and Borneo. Conte-Grand et al., (2017) suggested that this species (excluding Sri Lankan specimens) is characterized by deep intraspecific divergences and hence could be split into multiple lineages.

\section{Geographical distribution of the Family Channidae in Sri Lanka}

Genus Channa is distributed from Iran, Afghanistan, Pakistan in west, to China, Cambodia, Thailand, Vietnam and Philippines in the far-east, as well as to Sri Lanka, Nepal, Burma India and Bangladesh in the south (Pethiyagoda, 1991; Talwar and Jhingran, 1991; Conte-Grand et al., 2017). Genus Parachanna which is restricted to northeast Africa consists only of three species (Serrao 2014). The node separating the Genus Parachanna from Channa was estimated to be about 50 MYA (Benziger et al., 2011), which, corresponds to the timing of earliest Channid fossils (Archichanna and Eochanna) recorded from early Eocene by Roe (1991). Britze et al., (2019) described new genus Aenigmachanna from Kerala, South India with genetic distances ranging from $15.8-24.2 \%$ in $C O 1$ gene for the species of Channa, and with $20.4-22.2 \%$ in $C O 1$ gene for species of Parachanna.

Channa striata is the most widespread species in the Asian region among the Sri Lankan members of the genus. It is distributed in Pakistan, India, 
Bangladesh, Nepal, Burma, Malay Archipelago, Thailand and South China (Talwar and Jhingran, 1991). Channa punctata also shows a wide range of distribution, which includes Afghanistan, Pakistan, India, Nepal, Bangladesh, Burma and Yunnan (China) in addition to Sri Lanka. Channa marulius, sister species of $C$. ara, is distributed in Pakistan, India, Bangladesh, Nepal, Burma, Thailand, China and Sri Lanka. While Channa kelaartii is found from Sri Lanka and south India, C. gachua, the sister species of C. kelaartii and the Sri Lankan endemic Channa orientalis is distributed in Afghanistan, Pakistan, India, Bangladesh, Boneo, Iran, Malaysia, Myanmar, Nepal and Thailand. Currently known pattern of distribution of the Sri Lankan endemic Channid species and their congeners indicates a close biogeographical affinity of Sri Lankan species to those of mainland India and other Asian landmasses. Findings of the recent publications such as Conte-Grand et al., (2017) and Sudasinghe et al., $(2020 \mathrm{a}, \mathrm{b})$ provide evidence to the origins of Sri Lankan Channid taxa and their biogeographical affinities, which needs a further consolidated effort to visualize the complete picture of their evolutionary history in Sri Lanka.

When the ichthyo-zoogeography of India is considered, Gurumayum and Tamang (2016) recorded the following species from northeast India in the Brahmaputra drainage system: Channa punctata (Bloch, 1793), C. striata (Bloch, 1793), C. gachua (Hamilton, 1822), C. marulius (Hamilton, 1822), Channa barca (Hamilton, 1822), C. amphibeus (McClelland, 1845), C. stewartii (Playfair, 1867), and C. bleheri (Vierke, 1991) together with recently described species of C. aurantimaculata Musikasinthorn, 2000, C. melanostigma Geetakumari \& Vishwanath, 2011, C. andrao Britz, 2013, and C. pardalis Knight, 2016. On the other hand, Channa striata (Bloch, 1793), C. gachua (Hamilton, 1822), C. marulius (Hamilton, 1822), C. pseudomarulius (Hamilton, 1822), C. punctata (Bloch, 1793), and Channa diplogramma (Day, 1865) were recorded from southern India (Benziger et al., 2011; Jayaram, 1999). Hora's (1949) Sathpura hypothesis on the dispersal of Malayan fauna and flora to peninsular India, proposed to explain the patterns of distribution in the Indo-Sri Lankan freshwater fishes, has suggested biogeographic links between Indian and Malayan regions, and it requires further investigation. The genus Channa is also found in both these regions, while it is interesting to note the high diversity of the genus in north-east India (Gurumayum and Tamang, 2016), which indicates a transition zone between the Indian and Malayan regions. However, the complete picture of the biogeographical affinities, dispersal \& vicariance processes and speciation events within the family Channidae in the Indian sub-continent including Sri Lanka is yet to be understood.

Distribution of the family Channidae within Sri Lanka is reviewed and presented here, for which we have examined all the available distribution records for the valid species of Sri Lankan Channids, on a template of the ichthyological zones of the island (Senanayake and Moyle, 1982). The results of this comprehensive distribution review are summarized in Figure 2, while the Supplementary Appendix 1 provides a comprehensive database of all records up to date.

In addition to the distribution data from historical field surveys on Sri Lankan freshwater fishes by Senanayake (1980) and Pethiyagoda (1991) and the most recent distribution study by De Silva et al., (2015), our compilation of Channa distribution records include other available localities of opportunistic records of such specimens by Deraniyagala $(1929,1952)$, Radda (1973), Ranasinghe and Ratnayake (1992), Maduranga (2005) and Perera et al., (2014), as well as the currently available verified Channa specimens examined from the National Museum of Natural History, Colombo. Further, new localities presented in Sudasinghe et al., (2020a) have also been included in this distribution review. However, due to (a) the inability to assign historical distribution records available in above literature to one of the recently revised species of Channa marulius group (i.e. C. marulius, C. ara and $C$. cf. ara sensu Sudasinghe et al., 2020a) and (b) the taxonomic ambiguities in the said group, we have assigned all available distribution records for $C$. marulius group into a single distribution map, together with all historical distribution data for C. marulius. All distribution maps provided by Senanayake (1980), Pethiyagoda (1991), De Silva et al., (2015) and Sudasinghe et al., (2020a), 
were georeferenced and geographic coordinates were assigned to all distribution localities using the Calculate Geometry tool in ArcGIS 10.4.2 software by the Environmental Systems Research Institute (ESRI). Other distribution points provided in references without a map or geographic coordinates were navigated using a location search in Google Earth and indicated in maps with a different symbol indicating the uncertainty of exact locality (see Figure 2; Supplementary online appendix 1).
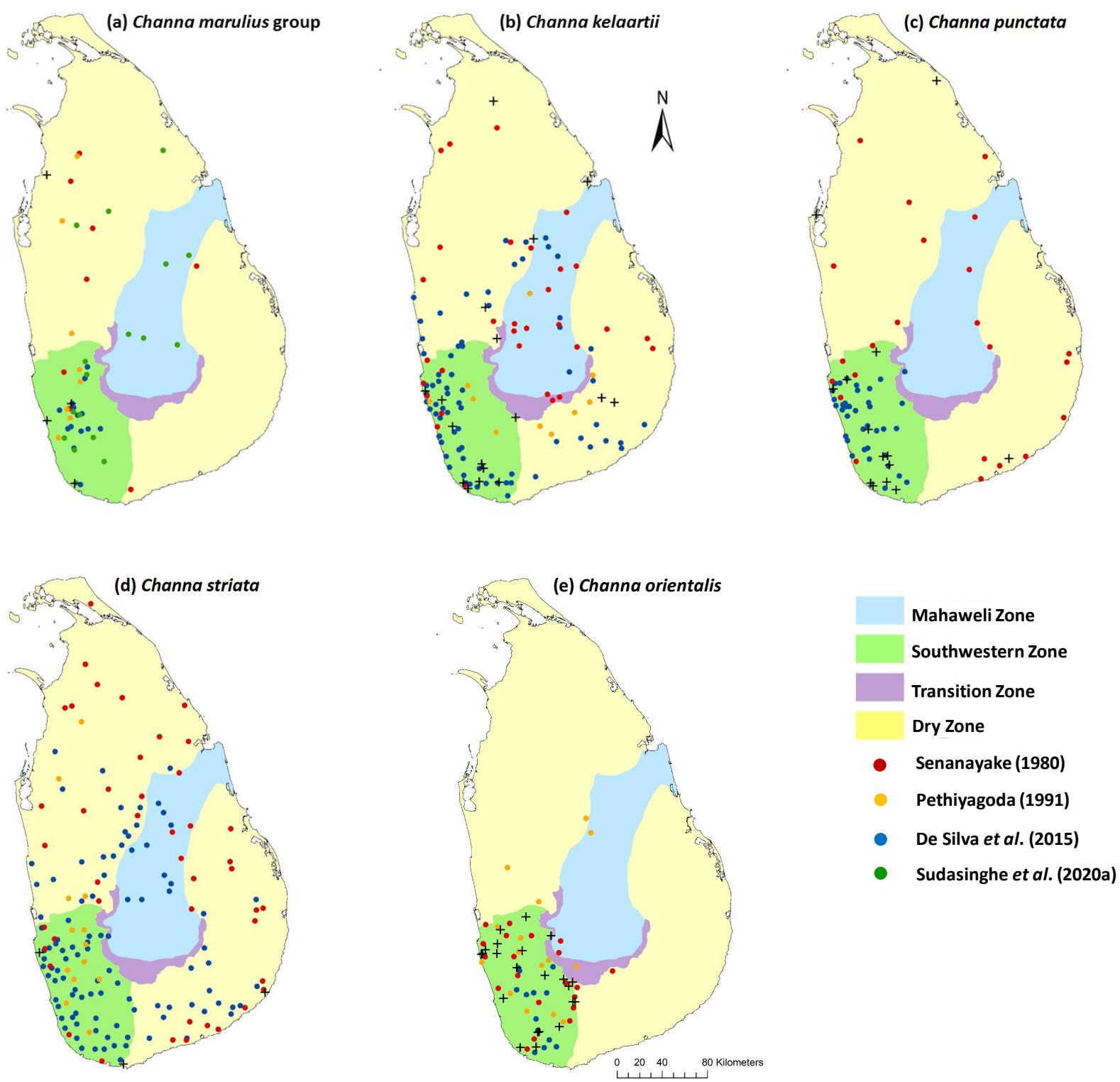

Figure 02: Distribution of valid taxa belonging to family Channidae in Sri Lanka based on freshwater fish surveys of the island by Senanayake, (1980) [Red closed circles], Pethiyagoda (1991) [Orange closed circles] and De Silva et al., (2015) [Blue closed circles] supplemented by other localities [Black crosses] provided for opportunistic records by Deraniyagala (1929, 1952, 1963); Radda (1973); Ranasinghe and Ratnayake (1992); Maduranga (2005) and Perera et al., (2014) and all verified specimens in the National Museum of Sri Lanka, Colombo. All new distribution records of Sudasinghe at al., (2020a) [Green closed circles] are assigned to Channa marulius group, without considering his recent taxonomic treatment due to reasons explained in the text). All distribution points are mapped on the template of Ichthyological zones of Sri Lanka (Senanayake and Moyle, 1982: Mahaweli zone - light blue, Dry zone - light yellow, Southwestern zone - light green and a Transition zone - light purple). 
Senanayake and Moyle (1982) have identified four ichthyological zones within Sri Lanka based on the distribution patterns of freshwater fish at the level of river basins, namely the Mahaweli zone, Dry zone, Southwestern zone and a Transition zone (in between the boundary of headwater regions of the Mahaweli zone and the other three zones). Distribution data from Senanayake (1980) and Pethiyagoda (1991) have recorded Channa marulius, C. striata, C. punctata and C. kellartii (C. gachua) from the South-western, Dry as well as the Mahaweli ichthyological zones. On the other hand, according to the most recent data by De Silva et al., (2015), Channa marulius, $C$. orientalis and C. punctata are restricted only to the South-western Ichthyological Zone of Sri Lanka (see Figure 2). Several authors have provided evidence for population declines and local extinction of freshwater fishes of Sri Lanka (Senanayake \& Moyle, 1982; Pethiyagoda 1994), but none particularly on Channids as yet. However, all aforementioned surveys have had their focus on the entire freshwater fish fauna of the island, which could have undoubtedly diluted the efforts on searching for individual species or groups in each and every major river basin. Overlooking Channa species in such general surveys are obvious due to their nocturnal and specialist carnivore habits. Hence it is important to conduct an island wide survey particularly targeting the species in the genus Channa, representing all major river basins of the island.

Although the icthiological zones are established for Sri Lanka, those are primarily delimited based on intuitive discernment upon extensive field expertise as of many such initial works elsewhere in the world (Perera et al., 2011) and have not yet been proven through a subsequent numerical analysis (as in Perera et al., 2018), while a substantial attempt has not yet been received to predict the distribution of freshwater fish species including Channids in Sri Lanka. Therefore, it is believed that an ecological niche modeling attempt could pave the way to better understand the biogeography and distribution of Channids in the Indian sub-continent including Sri Lanka, while supporting a future numerical confirmation of the intuitively delimited ichthyological zones. Cobos et al., (2019), discussed the applicability of Maxent for ecological niche modeling and
Phillips et al., (2006) shows the importance of Maxent as a presence-only modeling method, which follows the same approach used in traditional/intuitive ichthyological zonation in Sri Lanka, but with a rigorous processing of available data both on the species occurrence as well as predictor environmental variables. The species incidence and environmental data sets available for an ecological niche modeling exercise using Maxent to predict the possible distribution of Channiade in Sri Lanka needs to be tested for their completeness and resolution. This software uses a set of environmental grids and occurrence localities (species incidences) and the model expresses a probability distribution where each grid cell has a predicted suitability of conditions for the species (Steven et al., 2019). We argue that, although not at a fine grain of resolution, the Channid incidence data available for Sri Lanka supplemented with new findings from a rapid survey covering all major river basins of the island would yield a much better understanding to their evolution and biogeography. A reevaluation of the Ichthyological zones of Sri Lanka with results from ecological niche models would certainly shed new light to Sri Lankan freshwater biogeographical studies. Further, such complete data sets including modeled distribution would support analyses on patterns of endemism (Ramdhani et al., 2010; Perera et al., 2018; Perera et al., 2019) necessary for scientific conservation planning.

\section{Molecular Systematics of family Channidae}

Molecular Phylogenetic studies are being increasingly and rigorously used in fish taxonomy to determine the species limits and their status, describe new species, resolve taxonomic puzzles and investigate phylogenetic relationships (Benziger et al., 2011; Khare et al., 2014; Conte-Grand et al., 2017; Adamson and Britz, 2018; Sudasinghe et al., 2020a; Sudasinghe et al., 2020b). Starting with single gene sequence analysis of ribosomal DNA, mitochondrial and nuclear DNA approaches are dominated in molecular systematics today (Ward et al., 2005). DNA sequence analysis has been used for many years to assist species identifications, 
but different gene sequences have been used for different taxonomic groups and in different laboratories (Hebert et al., 2003). To solve these dissimilarities in molecular taxonomy and species demarcation, first, mitochondrial gene cytochrome c oxidase I ( $\mathrm{COI}$ ) was introduced for the global bio-identification system for animals which is also known as DNA barcoding and later cytochrome b (cytb) was also introduced (Hebert et al., 2003, Hellberg et al., 2014)

Due to the possible presence of mobile introns and low PCR success in $\mathrm{CO} 1$ based barcoding in some cases, another mitochondrial DNA; NADH dehydrogenase subunit 2 (ND2), has been successfully used as a secondary or alternative barcoding gene in fish (Kocher et al., 1995, Mohapatra et al., 2018). However, nuclear genes such as the internal transcribed spacers (ITS) of rRNA genes have also been used for testing phylogeographic patterns of closely related species due to their high evolutionary rates (Presa et al., 2002).

Several studies have been conducted to investigate molecular biology and phylogeny of genus Channa during the past few decades including preliminary barcodingg studies (Serrao et. al., 2014; Conte-Grand et al., 2017). Some researches (Benziger et al., 2011; ConteGrand et al., 2017) have studied the inter-species genetic variation of Channa, while few others (Jamaluddin et al., 2011, Bhat et al., 2014) have worked on the population genetics of the species. Phylogenetic studies have also helped resolving several taxonomic issues within the family Channidae. For example, Benziger et al., (2011) revalidated the species status of Channa diplogramma. This species was first described in 1865 from India, but remained a taxonomic puzzle until the phylogenetic study was carried out by Benziger et al., (2011). Further, DNA barcoding studies on snakeheads by Conte-Grand et al., (2017) revealed that the records of Channa orientalis from India were misidentifications, confirming the species' endemicity to Sri Lanka.

Further, previous studies have revealed the high intraspecific divergence of the several Channid species including those found in Sri Lanka; Channa striata and C. punctata (Conte-Grand et al., 2017), across the region. In a study by AbolMunafi et al., (2007), authors analysed the partial sequences of the mitochondrial gene Cytochrome b on six Channid species; Channa marulioides, $C$. melasoma, C. lucius, C. gachua, C. micropeltes and $C$. striata to determine their phylogenetic relationships. They found that Channids are a taxonomically difficult but monophyletic group that have a single common ancestral design, but with a considerable morphological diversity. According to their study mitochondrial and ribosomal genes of Channa shows high interand intra-specific sequence variability.

Several genes have been used for phylogenetic studies by researchers. Tan et al., (2012) used mitochondrial ND5 gene to investigate the intraspecific phylogenetic pattern of Channa stritata while Jamsari et al., (2011) used cytochrome c oxidase subunit I to investigate the genetic structure of same species. 16S rRNA and Cytochrome c Oxidase I were used by Benziger et al., (2011) to revalidate C. diplogramma. ConteGrand et al., (2017) used the 343 CO $l$ sequences in their Channid barcoding study. Mitochondrial gene ND2 and adjacent tRNA genes were used by Li et al., (2012) to examine the molecular phylogenetics of several Channa species.

There is no universal protocol for the number of samples of each species required for a particular molecular phylogenetic or phylogeographic study. Literature shows varied number of sampled individuals even within the same research (Britz et al., 2017; Adamson and Britz, 2018). For example, barcoding Australian fish species project had been used one to 15 samples from each species with a mean number of 3.66 (Ward et al., 2005). Therefore, we propose at least three samples/specimens from each region or river basin or from each population belonging to a given species for a molecular biological study on the Channidae in Sri Lanka.

\section{CONCLUSIONS AND RECOMMENDATIONS}

Literature on taxonomy and biogeography of family Channidae in Sri Lanka as well as the south and soth-east Asian region indicate an incomplete 
knowledge including unresolved areas in species limits, their inter- and intra- specific phylogenetic relationships and the biosystematics as a whole. Taxonomy of Sri Lankan species of Channidae still depend on traditional morphology based taxonomical characterization and, have not been adequately supplemented by genetics based studies. Studies on molecular genetics, phylogenetic relationships, phylogeography and DNA barcoding of family Channidae are still in their initial stages in Sri Lanka, while being somewhat established on Indian species as well as in other regions of their range. Further, recent publications on Sri Lankan Channids (Sudasinghe et al., 2020a; Sudasinghe et al., 2020b) are filling some gaps in taxonomy and molicular systematics. Hence, the above findings integrated with ongoing baseline studies on Sri Lankan taxa is expected to shed new light on the current understanding of the family Channidae in Sri Lanka.

Due to the paucity of understanding on the origins and phylogenetic relationships among the Sri Lankan Channid species and their congeners, an initial DNA barcoding exercise to delimit species and an examination on their origins through a multilocus phylogeny is timely. Furthermore, a multiple gene based integrated molicular systematic study involving at least three specimens representing different ichthyological zones of all "putative" Channid species in Sri Lanka is an urgent requirement, which could lead to the development of a resolved phylogeny of the family Channidae. All in all, many taxonomic ambiguities within the genus Channa in Sri Lanka elaborated above demands a complete taxonomic reevaluation for the entire genus in Sri Lanka, involving a combination of morphological and molecular techniques, leading to a revision of the genus within the island.

The incompleteness of the knowledge on the distribution patterns of the Channid species in Sri Lanka, needs to be rectified based on a complete all island field survey to search for potential species of snakeheads representing all the major river basins of the island. In addition to the field surveys to document the distribution ranges, a GIS based species distribution mapping and distribution modelling study using the ecological niche modelling techniques (e.g. Maxent) is also a priority need for Channidae in Sri Lanka, so that field searches could be narrowed down and evidence-based conservation actions could be facilitated.

Snakeheads represent one of the biggest and the most exploited native freshwater species for food fish in Sri Lanka, and their use in ornamental trade is economically significant. These uncontrolled, unsustainable harvests from the wild, together with other anthropogenic pressures, would foreseeably trigger a sharp decline in snakehead populations in the country. Enhancing these stocks for extractive uses i.e. consumption and ornamental use as well as conservation, needs (a) clear identification of species and (b) a concise knowledge on their biogeographic limits. Any efforts made in this regard would be futile or even catastrophic without such knowledge as population decline and genetic degradation are imminent.

\section{ACKNOWLEDGMENT}

We thank the Department of Wildlife Conservation, especially to M.G.C. Sooriyabandara and L. Peiris, for permitting to conduct field work in Protected Areas under their custody (DWC Research Permit Ref. WL/3/2/62/17) and Ms. Sanju Kasthuriarachchi and Ms. Lankani Somarathne of the of Natural History Museum of Sri Lanka for allowing access to the specimens and documents in their collection. We are grateful to Mr. P.S.K. Patabendi Mr. Kasun Priyadarshana, Dr. Kanishka B. Ukuwela, Mr. D. Kandmbi and Miss Hansani Ekanayake for their help in field investigations and Mr. Sampath de Alwis Goonatilake for the help with literature. Finally, we thank the Sabaragamuwa University of Sri Lanka research grant SUSL/RG/2016/09 for funding this project and two anonymous reviewers provided insightful comments on an earlier version of this manuscript. 


\section{REFERENCES}

Adamson E.A.S., and Britz R. (2018). The snakehead fish Channa aurolineata is a valid species (TeleosteiChannidae) distinct from Channa marulius. Zootaxa 4514 (4): 542-552.https://doi. org/10.11646/zootaxa.4514.4.7

Abol-munafi A.B., Ambak M.Z, Patimah I. and Bui M.T. (2007). Molecular Data from the Cytochrome b for the Phylogeny of Channidae (Channa sp.) in Malaysia, Biotechnology 6: 22-27. http:// dx.doi.org/10.3923/biotech.2007.22.27

Amarasinghe U. S., Shirantha R. R. A. R., and Wijeyaratne M. J. S. (2006). Some aspects of ecology of endemic freshwater fishes of Sri Lanka. In. Fauna of Sri Lanka: Status of Taxonomy, Research and Conservation. The World Conservation Union, Colombo, Sri Lanka, and Government of Sri Lanka. pp. 113-124.

Benziger A., Philip S., Raghavan R., Anvar Ali P.H., Sukumarn M. et al., (2011). Unraveling a 146 years old taxonomic puzzle: validation of Malabar Snakehead, species status and its relevance for Channid systematic and Evolution, PLoS ONE 6 (6): 1-12 https://doi.org/10.1371/journal. pone. 0021272

Bhat A.A., Haniffa M.A., Milton M.J., Paray B.H., Divya P.R. and Gopalakrishnan A. (2014). Genetic variation of striped snakehead (Channa striatus), International Journal of Biodiversity and Conservation 6 (5):362-372. https://doi.org/10.5897/ijbc2013.0649

Britz R., Adamson E., Raghawan R, Ali A. and Dahanukar N. (2017). Channa pseudomarulius, a valid species of snakehead from the Western Ghats region of peninsular India (Teleostei: Channidae), with comments on Ophicephalus grandinosus, O. theophrasti and O. leucopunctatus, Zootaxa 4299 (4): 529-545. DOI:https://doi.org/10.11646/zootaxa.4299.4.4

Britz R., Anoop V.K., Dahanukar N. and Raghavan R. (2019). The subterranean Aenigmachanna gollum, a new genus and species of snakehead (Teleostei: Channidae) from Kerala, South India. Zootaxa 4603 (2): 377-388. DOI: https://doi.org/10.11646/zootaxa.4603.2.10.

Cobos ME, Peterson AT, Barve N \& Osorio-Olvera L. (2019). kuenm: an R package for detailed development of ecological niche models using Maxent. PeerJ, the Journal of Life and Environmental Sciences 7: DOI: http://doi.org/10.7717/peerj.6281

Conte-Grand C., Britz R., Dahanukar N. Raghawan R., Pethiyagoda R., Tan H.H., et al., (2017). Barcoding Snakeheads (Teleostei, Channidae) revisited: discovering greater species diversity and resolving perpetuated taxonomic confusions. PLoS ONE 12 (9) 1-24 https://doi.org/10.1371/ journal.pone. 0184017

Courtenay W.R. and Williams J.D. (2004). Snakeheads (Pisces, Channidae)—A Biological Synopsis and Risk Assessment, U.S. Geological Survey. 151. https://doi.org/10.3133/cir1251

Deraniyagala P.E.P. (1929). The Labyrinthici of Ceylon. Spolia Zeylanica 15: 79-104

Deraniyagala P.E.P. (1932). Ichthyological Notes. The systematic position of the genus Channa. Spolia Zeylanica, 17, $40-41$.

Deraniyagala P.E.P. (1945). New subspecies among Ophiocephali of Ceylon and India. Spolia Zeylanica 24 (ii) 93

Deraniyagala P. E. P. (1952). A Colored atlas of some vertebrates from Ceylon, Vol. 1, Fishes. Ceylon Natural Museum Publications, Colombo, Sri Lanka,149pp. 
Deraniyagala P. E. P. (1963). The distribution of the genus Channa Gronov 1763 in Ceylon. Spolia Zeylanica, 30, $71-74$.

De Silva., Hapurachchi N., and Jayaratne T. (2015). Sri Lankan Freshwater Fishes. Wildlife Conservation Society, Galle, Sri Lanka, 391pp.

Duncker G. (1912). Die Süsswasserfische Ceylons. Jahrbuch der Hamburgischen Wissenschaftlichen Anstalten, Beiheft 2, Mitteilungen aus dem Naturhistorischen Museum in Hamburg, 29, 241272.

Goonatilake S de A. (2007). Freshwater fishes of Sri Lanka. Ministry of Environment, Colombo, Sri Lanka,135pp.

Goonatilake S de A. (2012). The Taxonomy and Conservation Status of the Freshwater Fishes in Sri Lanka. In: Weerakoon, D.K. \& S. Wijesundara (Eds.) The National Red List 2012 of Sri Lanka; Conservation Status of the Fauna and Flora., Ministry of Environment, Colombo, Sri Lanka. 77-87.

Goonatilake S de A. et al., (2020). The National Red List of Sri Lanka: Assessment of the Threat Status of the Freshwater Fishes of Sri Lanka, IUCN International Union for Conservation of Nature and Natural Resources and the Biodiversity Secratarite of Ministry of Environment and Wildlife Resources, Colombo, Sri Lanka. Pp. xv+106pp.

Gunther A. (1861). Catalogue of the fishes in the British Museum. Catalogue of the acanthopterygian fishes in the collection ofthe British Museum. Vol. 3. London, Taylor \& Francis. xxv+586pp.

Gurumayum S. D. and Tamang L. (2016). Channa pomanensis, a new species of snakehead (Teleostei: Channidae) from Arunachal Pradesh, northeastern India. Species 17 (57): 175-186.

Hebert P.D.N., Cywinska A., Ball S.L. and de Waard J.R. (2003). Biological identifications through DNA barcodes. Proceeding of Royal Society B London. B. 270: Pp. 313-321. DOI 10.1098/ rspb.2002.2218

Hellberg R.S., Kawalek M.D., Van K.T., Shen Y., and Williams-Hill D.M. (2014) Comparison of DNA extraction and PCR setup methods for use in high-throughput DNA Barcoding of fish species. Food Anal Methods. 7(10):1950-1959.

Hora S. L. (1949). Symposium on the Satpura hypothesis of the distribution of the Malayan fauna and flora to Peninsular India. Proceeding of National institute of Science India, 15 (B): 309-314

Jamsari A. F. F, Pau T.M., and Siti-Azizah M.N. (2011). Genetic structure of the snakehead murrel, Channa striata (channidae) based on the cytochrome c oxidase subunit I gene: Influence of historical and geomorphological factors. Genetics and Molecular Biology 34 (1): 152-160. https://doi.org/10.1590/S1415-47572011000100026

Jayaram K.C. (1999). The Freshwater Fishes of Indian Region. Narendra Publishing House, Delhi, India. 551pp.

Karrer C., Whitehead P.J.P. and Paepke H.J. (1994). Bloch \& Schneider's Systema Ichthyologiae, 1801: history and authorship of fish names, Zoosystematics and Evolution 70 (1): 99-111. https://doi.org/10.1002/mmnz.19940700105

Khare P., Mohindra V., Barman A.S., Singh R.K. and Lal K.K. (2014). Molecular evidence to reconcile taxonomic instability in mahseer species (Pisces: Cyprinidae) of India, Organisms Diversity \& Evolution 14: 307-326. http://dx.doi.org/10.1007/s13127-014-0172-8 
Kocher T.D., Conroy J.A., McKay K.R., Stauffer J.R., and Lockwood S.F. (1995). Evolution of NADH Dehydrogenase subunit 2 in East African Cichlid fish, Molecular Phylogenetics \& Evolution 4: 420-432.

Kotteilat M. (2013). The fishes of the inland waters of southeast Asia: a catalogue and core bibiography of the fishes known to occur in freshwaters, mangroves and estuaries. Raffles Bulletin of Zoology, 27 (Supplement), $1-663 p p$.

Li X., Musikasinthorn P. and Kumazawa Y. (2006). Molecular phylogenetic analyses of snakeheads (Perciformes: Channidae) using mitochondrial DNA sequences, Ichthyological Research 53: 148-159.10.1590/S1415-47572011000100026

Maduranga H.G.S. (2005). Ichthyofauna of bellanwila-Attidiya sanctuary and its Environs in Colombo, Sri Lanka. Tigerpaper. 32(1): 26-32.

Mahapatra S.D., Chkrapani V. P, Rasal K.D., Barman H.K. and Subudhi E. (2018). Characterization and expression analysis of Nadh Dehydrogenase (Ubiquinone) Iron-Sulfur Protein-2 in Channa striatus exposed to Hypoxia, Research Journal of Biotechnology 13 (1): 1-10.

Mendis A.S. and Fernando C.H. (1962). A Guide to freshwater fauna of Ceylon, Bulletin No 12. Fisheries Research Station, Department of Fisheries, Ceylon. 160 pp

Mishra S.S., Das A. and Barman R.P. (2014). Notes on some snakehead fishes of India with an aid to their identification. Records of the Zoological Survey of India: 113 (Part-2): 145-152.

Munro I.S.R., (1955). The marine and fresh water fishes of Ceylon. Halstead Press, Sydney, Australia. xvi, 351pp.

Mustafa A., Sujuti H., Permatasari N. and Widodo M.A. (2013). Determination of Nutrient Contents and Amino acid Composition of Pasuruan Channa striata Extract, IEESE. International Journal of Science and Technology 2 (4): 1-11.

Perera N., Goonatilake A. de S., Wadugodapitiya A., de Silva G. and Weerakoon D. (2014). Descriptive guide to Galapitamada-Home of the Critically Endangered Bandula Barb, IUCN Sri Lanka country office, 28pp.

Perera S.J., Ratnayake-Perera D. and Procheş Ş. (2011). Vertebrate distributions indicate a greater Maputaland-Pondoland-Albany region of endemism. South African Journal of Science 107: 49-63. http://dx.doi.org/10.4102/sajs.v107i7/8.462

Perera S.J., Procheş Ş., Ratnayake-Perera D. and Ramdhani S.V (2018). Vertebrate endemism in south-eastern Africa numerically redefines a biodiversity hotspot. Zootaxa 4382(1), 56-92. https://doi.org/10.11646/zootaxa.4382.1.2

Perera S., Surasinghe T., Somaweera R., Ramdhani S. and Karunaratne S (2019). Hyper-hotspots within a biodiversity hotspot: Patterns of reptile endemism in Sri Lanka. Proceedings of the Asia Pacific Conference of the Association for Tropical Biology and Conservation, Thulhiriya, 10-13 November 2019. Association for Tropical Biology and Conservation, Colombo, Sri Lanka. p. 63.

Pethiyagoda R., (1991). Freshwater fishes of Sri Lanka. Wildlife Heritage Trust of Sri Lanka, Colombo, Sri Lanka, 362pp.

Pethiyagoda R. (1994). Threats to the indigenous freshwater fishes of Sri Lanka and remarks on their conservation, Hydrobiologia 285 (1-3): 189-201. 
Phillips S.J., Anderson R.P. and Schapire R.E. (2006). Maximum entropy modeling of species geographic distributions. Ecological Modelling 190 (3-4): 231-259. https://doi.org/10.1016/j. ecolmodel.2005.03.026

Phillips S.J., Anderson R.P. and Schapire R.E. (2006). Maximum entropy modeling of species geographic distributions. Ecological Modelling 190 (3-4): 231-259. https://doi.org/10.1016/j. ecolmodel.2005.03.026

Praveenraj J., Uma A., Mouiitharan, N. and Kannan, R. (2019). Channa brunnea, a new species of snakehead (Teleostei: Channidae) from West Bengal, India. Zootaxa, 4624, 59 - 70. http:// dx.doi.org/10.11646/zootaxa.4624.1.4

Presa P., Pardo. B.G., Martinez P. and Bernatchez L. (2002). Phylogeographic Congruence Between mtDNA and rDNA ITS Markers in Brown Trout, Journal of Molecular Biology and Evolution. 19(2) 2161-2175.

Radda A.C. (1973). Collection of Fishes (Osteichthyes). Results of the Austrian-Ceylonese Hydrobiological mission. Bulletin of the Fisheries Research Station Sri Lanka (Ceylon). 24(1\&2): 135-151.

Ramdhani S., Perera S. J. and Proches S. (2010). Introducing a Quarter Degree Grid System for Sri Lanka as a Biogeographical Tool. Proceedings of the Third International Symposium of Sabaragamuwa University of Sri Lanka. 26 - 28 August 2010, Belihuloya. Sabaragamuwa University of Sri Lanka, Belihuloya, Sri Lanka. p. 10.

Ranasinghe P.N. and Ratnayake A. (1992). Fauna and Flora of Dombagaskanda Forest, and its Conservation. Young Zoologists Association of Sri Lanka. 33pp.

Roe L.J. (1991) Phylogenetic and ecological significance of Channidae (Osteichthyes, Teleostei) from the early Eocene Kuldana Formation of Kohat, Pakistan. Contributions from the Museum of Paleontology, University of Michigan 28(5):93-100, <http://hdl.handle.net/2027.42/48541>

Sclater P. L. (1858). On the general geographical distribution of the members of the class Aves. Journal of the Proceedings of the Linnean Society of London. Zoology 2 (7): 130-136.

Senanayake F. R. (1980). The biogeography and ecology of inland fishes of Sri Lanka. Ph.D. dissertation. University of California, USA, 407pp.

Senanayake F. R. and Moyle P. B. (1982). Conservation of freshwater fishes of Sri Lanka. Biological Conservation 22 (1): 81-195.

Serrao N.R., Steinke D. \& Hanner R.H. (2014). Calibrating Snakehead Diversity with DNA Barcodes: Expanding Taxonomic Coverage to Enable Identification of Potential and Established Invasive Species. PLoS ONE 9 (6): e99546. doi:10.1371/journal.pone.0099546

Sharma N.K., Mir J.I., Singh R., Akhtar M.S. and Pandey N.N. (2015). Length-weight relationships for eight fish species from the Ravi River, north-western India. Journal of applied ichthyology 31: 1146-1147. https://doi.org/10.1111/jai.12836

Steven J. P., Dudík M., and Schapire R.E. (2019). [Internet] Maxent software for modeling species niches and distributions (Version 3.4.1). Available from url: http://biodiversityinformatics. amnh.org/open_source/maxent/.Accessed on 2019-6-30. 
Sudasinghe H., Adamson E.A.S. et al.(2020a). Unexpected species diversity within Sri Lanka's snakehead fishes of the Channa marulius group (Teleostei: Channidae), Zootaxa 4747 (1): 113-132. DOI: https://doi.org/10.11646/zootaxa.4747.1.4.

Sudasinghe H., Pethiyagoda R. et al., (2020b), Channa kelaartii, a valid species of dwarf snakehead from Sri Lanka and southern peninsular India (Teleostei: Channidae), Vertebrate Zoology 70 (2): 157-170. DOI: DOI: 10.26049/VZ70-2-2020-05

Talwar P.K. and Jhingran A.G. (1991). Inland Fishes of India and Adjacent Countries, Vol 1\&2, Oxford \& IBH Publishing Co. Pvt. Ltd. New Delhi, India, 1158pp.

Tan M. P., Jamsari A. F. J. and Azizah M. N.S. (2012). Phylogeographic Pattern of the Striped Snakehead, Channa striata in Sundaland: Ancient River Connectivity, Geographical Anthropogenic Singnatures. PLOS ONE 8 (5) https://doi.org/10.1371/annotation/2be4a0a9b3ed-492f-8c4d-15d3a5ae6cab

Wallace A.R. (1876). The geographical distribution of animals. Harper \& Brothers, New York, USA.

Ward R. D., Zemlak T.S, Innes B.H., Last P.R. and Hebert P.D.N. (2005). DNA barcoding Australia's fish species, Philosophical Transaction of Royal Society B. 360: 1847-1857

Wimalasena S. and Jayasuriya M.N.S. (1996). Nutrient analysis of some fresh water fish, Journal of. National Science Foundation Sri Lanka. 24 (1): 21-26. http://doi.org/10.4038/jnsfsr.v24i1.5535

Willey A. (1909). Observations on the Nests, Eggs, and Larvae of Ophiocephalus striatus. Spolia Zeylanica, 6 (23), 108-123.

Willey A. (1910). Notes on the fresh-water fisheries of Ceylon. Spolia Zeylanica, 7 (26), 88-105. 